\title{
KAJIAN PAI PARA PELAJAR DALAM PUSARAN DUNIA VIRTUAL
}

\author{
Abdulloh Fuadi \\ UIN Sunan Gunung Djati Bandung, Jawa Barat, Indonesia \\ voeadi@gmail.com
}

\begin{abstract}
Abstrak
Pusaran dunia virtual terkini mengisyaratkan diperlukannya penelusuran tentang pemahaman para pelajar post-millenial yang terkungkung dalam dunia virtual yang digitalistik terhadap ajaran dasar agama Islam, yang terangkum dalam kajian dalam bidang Pendidikan Agama Islam. Dengan menggunakan metode kualitatif beserta berbagai perangkatnya, dan mendasarkan pada pemikiran tentang ruang publik virtual, penelitian ini mengungkapkan bahwa kesan ketegasan dan kekuatan terpancar dalam uraian para pelajar saat mereka mengungkapkan pemahaman mereka tentang makna agama Islam, pokok-pokok ajaran, sejarah, dan isu-isu keagamaan terkini.
\end{abstract}

Kata kunci: Ajaran Dasar Agama; Pelajar; Ruang Publik Virtual.

\begin{abstract}
The latest virtual world vortex suggests the need for a search to understand post-millennial students who are confined in a digitalistic virtual world toward the basic teachings of Islamic religion, summarized in the study of Islamic Religious Education. Using qualitative methods and their various tools, and based on thinking about virtual public spaces, this study revealed that the impression of assertiveness and strength radiated in students' description as they expressed their understanding on the meaning of Islam, the main points of teachings, history, and current religious issues.
\end{abstract}

Keywords: Basic Teachings of Religion; Student; Virtual Public Spaces. 


\section{PENDAHULUAN}

Empat isu yang merupakan kesimpulan dari penelitian yang dilakukan oleh Pusat Pengkajian Islam dan Masyarakat (PPIM) UIN Syarif Hidayatullah Jakarta pada tahun 2017 memberikan wawasan tentang apa yang sedang berlaku pada para peserta didik di sekolah tingkat menengah tentang informasi keagamaan yang mereka terima dalam dunia virtual. Keempat isu tersebut menggambarkan tentang adanya intoleransi dan radikalisme diantara para pelajar generasi terkini: 1) isu tentang aliran menyimpang; 2) isu tentang Islam sebagai korban; 3) isu tentang musuh agama Islam; 4) isu tentang jihad (Tim Pusat Pengkajian Islam dan Masyarakat, 2017, p. 36). Hal tersebut diindikasikan sebagai dampak dari kultur digital yang sedang melanda peradaban dewasa ini. Maka disebutkan juga bahwa pada level opini, para peserta didik cenderung memiliki pandangan keagamaan yang intoleran. Sekitar 58.5\% pandangan keagamaan siswa intoleran terdapat pada opini radikal, kemudian pada opini intoleransi internal sebanyak 51.1\%, sedang pada opini intoleransi eksternal sebanyak 34.3\%. Survei tersebut juga menunjukkan bahwa para pelajar lebih banyak menelusuri informasi keagamaan melalui dunia virtual, baik pada platform blog, website atau media sosial. Maka seakan tak terbantahkan bahwa dunia virtual dengan jaringan internetnya menjadi sandaran bagi generasi terkini dalam mengkaji pengetahuan keagamaan Islam. Temuan lain yang menarik dari survei tersebut adalah bahwa siswa yang tidak mempunyai akses internet lebih memiliki opini moderat dibandingkan yang memiliki akses internet.

Yang patut dijadikan catatan tersendiri dari fenomena di atas adalah bahwa massifikasi data pada dunia internet ternyata belum seiring sejalan dengan kebijaksanaan dan kearifan. Mereka yang begitu mudah terakses dengan internet ternyata cenderung intoleran pada 'yang lain' yang berbeda. Empat isu sekam bagi intoleransi dan radikalisme pada pelajar sebagaimana diperlihatkan oleh survei PPIM UIN Jakarta menunjukkan bahwa persepsi terhadap yang liyan, baik secara internal maupun eksternal keagamaan, oleh 
para pelajar tersebut perlu ditelusuri lebih lanjut.

Dalam hubungannya dengan identitas diri dan di luar diri, katagorisasi 'self' dan 'other' menjadi tak terhindarkan. Katagorisasi ini menjadi sesuatu yang integral dalam kehidupan sosial keagamaan (Kilp, 2011). Selaras dengan hal itu, wacana in-group dan out-group pun tak terhindarkan terbentuk dalam framework religiusitas suatu komunitas agama (Spears, 2011, p. 202). Para pelajar generasi terkini yang terkungkung dalam kultur digital, secara tidak disadari, berkelindan dengan paradigma yang diusung oleh jenis kultur ini. Paradigma kultur digital berorientasikan pada oposisi biner yang hanya mengenal dua hal yang saling berhadapan: on/off, hitam/putih, benar/salah, atas/bawah, luar/dalam, barat/timur, maskulin/feminin, join/leave, friend/unfriend, comment/no comment, dll. Dalam lingkup yang lebih luas, berpikir digital adalah juga berpikir oposisi biner: kita/mereka, kawan/lawan. Hal yang demikian berkebalikan dengan paradigma kultur analog yang berorientasi pada hubungan, spektrum, korespondensi, relasi, multiplisitas, dan variasi berkelanjutan (Piliang, 2017, p. 3). Kedewasaan religiusitas itu sendiri justru terbangun dalam pengalaman eksistensial yang kadangkala ambigu dan kontradiktif.

Berdasarkan pemikiran di atas, maka diperlukan penelusuran lebih lanjut tentang bagaimanakah pemahaman para pelajar terkini yang terkungkung dalam dunia virtual yang digitalistik terhadap ajaran dasar agama Islam. Hal ini penting dilakukan untuk melihat olahan para pelajar generasi post-millenial ini terhadap informasi keagamaan yang mereka terima, dimana informasi tersebut kebanyakan mereka terima dari ruang publik virtual.

\section{LANDASAN TEORI}

Perkembangan kontemporer menunjukkan bahwa ruang publik mengalami perkembangan pesat seiring tumbuhnya ICT (information communication technology) yang melahirkan ruang publik virtual. Ruang ini 
begitu menarik karena merupakan 'ruang imajiner' atau 'maya' yang bersifat artifisial, dimana setiap orang dapat melakukan apapun yang biasa dilakukan dalam kehidupan sehari-hari tapi dengan cara yang baru. Hal-hal menarik tersebut antara lain adalah: (1) identitas aktor-aktor tersembunyi di balik tanda; (2) isu-isu terkini tersebar dengan cepat dan menjangkau penerima yang amat luas tanpa dibatasi ruang dan waktu; (3) masyarakat diarahkan untuk mengembangkan hidupnya melalui jejaring (the network society) (Wulan Pujiriyani, 2013).

Keterhubungan antara individu dalam network society bersifat sangat cair di mana satu individu bisa berinteraksi dengan berbagai sumber. Model masyarakat terhubung inilah yang kemudian membawa dampak besar dalam berbagai bidang kehidupan, begitu pula dalam bidang pemerolehan informasi keagamaan. Di dalam network society, informasi menjadi pusat dari keterkaitan antara berbagai elemen dalam masyarakat (Dwiana, 2013).

Grup-grup diskusi maupun forum perbincangan sebagai respon dari realitas di daring merupakan salah satu perwujudan ruang publik di era internet saat ini sebagai pengganti ruang baca, perpustakaan, kafe, dan tempat-tempat lain yang telah menjelma menjadi sebagai virtual sphere atau ruang virtual. Ruang virtual yang memfasilitasi publik untuk melakukan interaksi melalui beragam jenis komunikasi internet.

Melalui pendekatan kultural, ruang publik virtual melahirkan budaya baru dalam pemerolehan informasi. Tidak ada lagi batasan antar individu, baik yang memahami perihal keagamaan dengan baik maupun yang tidak cakap. Siapa pun bisa melibatkan dirinya dalam interasi intelektual tersebut. Sebuah isu keagamaan bahkan bisa menjadi informasi yang sangat cepat tersebar dan langsung bisa dijadikan topik perdebatan. Juga, ini merupakan efek yang tidak bisa terelakkan. Ruang virtual menyuburkan gerakan yang beragam, mulai dari gerakan akar rumput hingga aktivitas terorisme yang menggunakan internet sebagai ruang bebas untuk menyebarkan paham dan keyakinan. 
Beberapa pandangan berikut menunjukkan betapa ruang publik virtual tersebut menyimpan potensi positif dan optimis (cyberoptimist) sekaligus negatif dan pesimis (cyberpessimist). Pandangan pertama memiliki keyakinan bahwa ruang publik virtual mampu membuka kemungkinan luas terbangunnya komunikasi dan interaksi bagi segenap warga negara tanpa sekat-sekat ideologi, dan agama. Ruang publik virtual memfasilitasi tumbuhnya entitas yang leluasa mengembangkan dialog publik menanggapi berbagai isu. Wacana yang dibangun berdasarkan diskusi ilmiah demi kepentingan bersama. Pandangan ini menekankan bahwa ruang virtual setidaknya telah memberikan kesempatan lebih luas bagi entitas untuk bertukar pikiran. Proses ini pun tidak lepas dari penyadaran diri khalayak yang terlibat dalam ruang virtual.

Pandangan kedua menekankan pada legitimasi yang berada dalam wacana yang dikonstruk dalam debat kritis karena ruang publik yang terjadi adalah ruang publik virtual yang sangat bias dari keterwakilan. Oleh sebab itu, ruang publik yang ada pada dasarnya tidak mewakili siapa pun karena kaburnya identitas dari entitas yang terlibat dalam ruang publik virtual tersebut. Hal ini terutama terkait dengan maraknya fake information (informasi palsu), atau yang biasa disebut dengan istilah hoax. Meskipun demikian, masih ada juga kritik yang menyatakan bahwa terdapat banyak ruang virtual untuk diskusi, sehingga para pengguna justru dapat menentukan sendiri pilihannya tentang ruang virtual mana yang mau mereka ikuti (Nasrullah, 2012).

\section{METODE}

Secara umum penelitian ini didasarkan pada pendekatan kualitatif, data yang dikumpulkan juga merupakan data kualitatif yakni data yang disajikan dalam bentuk kata verbal (Bogdan \& Biklen, 1982, p. 2). Penelitian ini dilaksanakan di institusi pendidikan level menengah atas, yaitu Sekolah Menengah Atas (SMA). Teknik purposive sampling digunakan dalam 
penelitian ini berdasarkan pada pilihan yang disengaja pada seorang responden karena kualitas yang dimiliki responden tersebut. Teknik pengumpulan data dengan wawancara adalah teknik utama yang digunakan. Peneliti menggunakan wawancara tidak terstruktur atau terbuka (bebas). Peneliti tidak menggunakan pedoman wawancara yang telah tersusun secara sistematis dan lengkap untuk mengumpulkan datanya (Sugiyono, 2012, p. 320). Dalam menganalisa data, peneliti menggunakan analisa data induktif. Analisa data induktif yaitu proses mengorganisasikan fakta-fakta atau hasilhasil pengamatan yang terpisah-pisah menjadi suatu rangkaian hubungan (Azwar, 2010, p. 40).

\section{HASIL DAN PEMBAHASAN}

Penguasaan pengetahuan dasar dalam bidang agama mengisyaratkan bahwa seseorang mengerti aspek-aspek standar yang bertalian dengan berbagai alternatif yang bertalian dengan pemahaman keagamaannya. Dalam hal ini, pelajar Sekolah Menengah Atas memiliki pengetahuan tentang agama Islam yang tergali dari berbagai sumber dan media. Informasi keagamaan dasar yang tereksplorasi oleh pelajar tersebut terbagi menjadi beberapa tema, yaitu pemahaman pelajar tersebut tentang agamanya, pokok-pokok ajaran, sejarah, dan isu-isu keagamaan terkini. Secara garis besar, berbagai tema tersebut terangkum dalam pembahasan tentang PAI (Pendidikan Agama Islam) yang juga diajarkan di institusi Pendidikan. Data-data berikut memaparkan terlebih dahulu pemahaman keagamaan para pelajar tentang agama mereka, kemudian akan tergali asal-muasal pemerolehan informasi keagamaan tersebut yang ternyata kebanyakan bersumber dari dunia virtual digital.

Salah satu responden, Diaz Maulida (NISN. 0027730412), berbicara tentang informasi keagamaan yang ia ketahui. Pertama, ia menyampaikan tentang arti Islam. Diaz mengatakan bahwa arti Islam adalah selamat. Yang dimaksudkan dengan selamat pada agama ini yaitu bahwa Islam 
mengajarkan tata cara hidup secara Islami kepada setiap pemeluknya setiap saat. Diaz menguraikan pula makna selamat pada salam yang biasa diucapkan oleh orang Islam saat menyapa orang lain. Ia mengatakan bahwa makna salam berarti doa untuk orang yang disapa. Ketika orang tersebut membalas salam yang disampaikan, maka doa keselamatan tertuju juga kepada orang yang menyampaikannya pertama kali. Jadi, pengucapan salam yang dilakukan oleh umat agama ini berarti saling mendoakan untuk keselamatan antar sesama.

Tentang pokok-pokok dasar dari ajaran agama Islam, Diaz menyebutkan rukun Islam. Ia mernguraikannya satu per satu. Ia menyatakan bahwa mengucapkan kalimat Syahadat adalah syarat bagi seseorang menjadi seorang muslim. Karena menjadi syarat yang mutlak, maka pengucapan kalimat syahadat menjadi hal penting yang harus dilaksanakan, sehingga seseorang sah untuk disebut sebagai seorang muslim. Lalu Diaz menyebutkan kewajiban melaksanakan rukun Islam shalat. Shalat yang terdiri dari lima waktu adalah sebagai sarana bagi seorang Muslim untuk dekat kepada Tuhannya. Saat menyebutkan tentang kewajiban puasa ramadhan, Diaz menyatakan berikut: "Puasa itu gak cuman untuk menahan lapar dan haus, mulai dari pagi sampai sore hari. Tapi juga untuk melatih kesabaran kita. Di samping itu, puasa juga bagus juga untuk kesehatan. Dengan melaksanakan puasa berarti kita mengistirahatkan seluruh organ tubuh, sehingga nantinya akan menjadi lebih sehat dan bugar."

Kemudian Diaz menguraikan tentang sejarah agama Islam. Ia bercerita tentang kelahiran Nabi Muhammad. Sepengetahuannya, hati nabi Muhammad dibersihkan oleh malaikat sebelum diangkat menjadi seorang nabi dan rasul. Setelah proses pembersihan hati ini, maka nabi menjadi suci dan selalu dijaga untuk tidak berbuat dosa. Lalu Diaz pun menyatakan hal yang terkait dengan agama-agama terdahulu. Ia menyebutkan bahwa pengangkatan Muhammad sebagai rasul Allah mempunya tujuan untuk menyempurnakan agama-agama yang ada sebelumnya. 
Di samping informasi keagamaan yang terkait dengan sejarah, Diaz juga menyatakan beberapa hal tentang isu-isu keagamaan terkini. Ia mengungkapkan tentang kelompok ISIS (Islamic State of Iraq and Syria) di kawasan Timur Tengah. Dalam pandangan Diaz, kelompok ISIS bagaikan sebuah angkatan bersenjata, yang mempunyai berbagai sarana dan prasarana untuk melaksanakan kegiatan peperangan. Kelompok ISIS hendak memanfaatkan kaum Muslimin untuk memberontak kepada pemerintahan yang telah berdaulat, padahal, Diaz menyatakan, agama Islam tidak mengajarkan untuk memberontak. Diaz lalu mengungkapkan informasi terkait dana yang menyokong kelompok ini. Katanya, ISIS mendapatkan dana setiap bulan dari roda perekonomian ladang minyak dan gas. Karena itulah, dana yang terkumpul menjadi berlimpah. Dengan modal dana yang demikian, ISIS berusaha menguasai negara Irak dan Syria. Berikutnya, Diaz menyebutkan tentang asal muasal pembentukan kelompok ini, dengan menyatakan bahwa bukanlah umat Muslim yang mempunyai inisiatif untuk membentuknya, tetapi negara adi kuasalah yang melakukan hal tersebut.

Responden yang lain, Elza Khairunnisa Ramadani (NISN. 0018693327), mengungkapkan pemahamannya tentang agama Islam. Ia menyatakan bahwa Islam adalah agama yang tegas. Jika seseorang berbuat salah walau sedikit saja, maka ia akan mendapatkan ganjaran berupa dosa. Dengan demikian, dalam pandangan Elza, Islam adalah agama yang menuntut para pemeluknya untuk disiplin, sehingga umat Islam mestilah menjaga diri dalam melakukan suatu perbuatan karena ada akibat fatal yang bisa ditanggungnya itu.

Pokok ajaran agama yang diketahui oleh Elza adalah bahwa terdapat rukun Islam yang harus dijalani, serta rukun iman yang mesti dipercayai. Isuisu terkini terkait keagamaan yang diketahui oleh Elza hampir serupa dengan Diaz, yaitu adanya kelompok ISIS (Islamic State of Iraq and Syria). Kelompok ISIS, bagi Elza, termasuk ke dalam golongan Islam radikal. Mereka mewajibkan para pengikutnya yang perempuan untuk memakai cadar guna menutup aurat. Elza pun menegaskan bahwa Islam adalah agama yang 
mengajarkan perdamaian, sehingga tidak condong kepada peperangan.

Syavian Deniswara (NISN. 0026936740), saat diminta untuk mengungkapkan pengetahuannya tentang Islam, menyatakan bahwa arti Islam adalah damai. Dengan makna ini, maka berarti semua orang Islam mestilah menghormati orang lain yang berbeda agama dan keyakinan. Perbedaan keyakinan tersebut tidak menghalangi untuk menjalani kehidupan yang rukun dan saling menghargai. Kemudian Vian menyebutkan beberapa pokok ajaran agama Islam. Ia menyebutkan tentang rukun iman.

Saat menguraikan tentang kepercayaan kepada qadha dan qadar, Vian menyebutkan tentang pentakdiran jenis kelamin pada manusia. Dikatakannya bahwa manusia telah ditakdirkan terbagi menjadi dua jenis kelamin, yaitu laki-laki atau perempuan. Semua manusia mestilah menerima takdir tersebut. Tetapi ternyata dalam realitanya, ada yang tidak berkehendak menerima takdir tersebut, sehingga muncullah gerakan LGBT (lesbian, gay, biseksual, dan transgender). Padahal, menurutnya, tuhan telah mentakdirkan manusia untuk senang hanya kepada lawan jenis. Meski demikian, ternyata masih ada diantara mereka yang menyukai dengan sesama jenis.

Saat membicarakan tentang sejarah Islam, Vian menyebutkan tentang nasib yang dialami oleh kaum perempuan sebelum datangnya agama Islam. Dikatakannya bahwa sebelum era Islam datang, banyak terjadi penindasan terhadap kaum wanita. Diantara mereka ada yang dikubur hidup-hidup karena kelahirannya tidak dikehendaki oleh orang tuanya. Saat Islam datang, derajat kaum perempuam dihormati dan mendapat tempat kedudukan yang semestinya.

Berkenaan dengan isu-isu keagamaan terkini, Vian menyebutkan tentang kasus pertikaian antara Palestina dan Israel di jalur Gaza. Dikatakannya bahwa orang-orang Palestina rentan ditembak oleh para tentara Israel. Ia lalu menyebutkan tentang masjid al-aqsha, dimana orang-orang Palestina yang akan pergi ke masjid tersebut sering dihadang oleh personel keamanan 
Israel, sehingga mereka tidak bisa melaksanakan ibadah shalat sebagaimana mestinya.

Dengan nama panggilan Anu, Anugrah Ramadhan Rahandi (NISN. 0019092882) mengungkapkan pengetahuannya tentang agama Islam. Ketika membicarakan secara umum, Anu menyatakan bahwa Islam adalah agama yang ketat. Peraturannya beragam sekaligus banyak. Contoh kasus yang ia utarakan adalah tentang pakaian, terutama bagi muslimah. Pakaian bagi muslimah telah diatur sedemikian rupa sehingga menutupi aurat. Dalam pandangan Anu, peraturan yang demikian tidak ditemukan pada komunitas agama lain. Sedangkan Islam membahasnya secara detil sekaligus tegas.

Terkait tentang pokok-pokok ajaran Islam, Anu mengatakan tentang kewajiban shalat dan membaca Al-qur'an. Ia juga menyebutkan tentang sejarah Islam, yaitu perihal perang Salib dan peristiwa hijrah Nabi dari Mekkah ke Madinah. Isu-isu terkini juga didapatkan oleh Anu. Salah satu yang menyita perhatiannya saat ini terkait dengan isu terorisme. Dalam pandangannya, isu terorisme membuat citra Islam tidak baik. Islam menjadi tertuduh karena kasus tersebut, padahal tidak semua umat Islam melakukan aksi terorisme.

Responden yang lain, Farrel Abhista El Rasya (NISN. 0027044427), berujar tentang agama Islam secara umum. Farrel, demikian sebutan singkatnya, mengatakan bahwa arti Islam adalah damai. Islam merupakan rahmatan lil alamin. Maka dalam pandanganya, umat Islam tidak pernah memancing kekacauan kepada komunitas agama lain. Agama Islam penuh dengan hal-hal positif bagi umatnya. Farrel menambahkan bahwa Qur'an dan hadits adalah pedoman bagi umat Islam. Segala hal terkait dengan inti ajaran Islam telah termaktub di sana. Ia juga menyatakan beberapa hal terkait sejarah Islam, diantara adalah tentang perebutan kota Konstantinopel saat perang Salib, serta tentang perampasan tanah Palestina oleh Israel.

Disamping itu, Farrel juga mengikuti isu-isu terkini terkait keagamaan, diantaranya tentang kasus kerusuhan Tolikara di Papua yang berimbas pada 
pembakaran bangunan masjid. Farrel pun menilai bahwa toleransi di Indonesia kurang berjalan dengan baik karena terjadinya kasus tersebut. Sedang isu keagamaan secara internasional terkini yang Farrel ketahui adalah tentang Palestina dan kasus muslim Rohingya di Myanmar. Umat Islam di daerah Rohingya terusir dari tanah kelahirannya, dan saat ini mengungsi ke negara-negara tetangga.

Fito Agrianto (NISN. 0022790873), dipanggil dengan nama sebutan Fito, menyebutkan bahwa dalam agama Islam terdapat berbagai kewajiban. Juga ada perintah-perintah yang harus dilaksanakan, serta ada larangan-larangan yang mesti dijauhi. Ia lalu menyebutkan bahwa dasar dari semua perintah dan larangan itu adalah kitab suci, sehingga al-qur'an menjadi landasan keberagamaan. Kemudian Fito menyatakan tentang kebebasan yang diberikan kepada manusia, bahwasanya untuk memeluk agama Islam, tidak ada paksaan sama sekali. Terkait dengan pokok-pokok ajaran Islam, Fito menyebutkan tentang keimanan, bahwa dasar seseorang beragama adalah dengan mempercayai bahwa tuhan adalah Allah, karena hal itulah landasan utama dalam agama Islam.

Fito juga mengikuti perkembangan pengetahuan tentang isu-isu keagamaan terkini. Ia menyatakan bahwa di masa kini, beberapa orang dari umat Islam belum mencerminkan dirinya sebagai orang yang beragama. Fito pun menunjuk ke ranah waktu akhir jaman, dimana orang-orang tidak begitu peduli dengan ajaran agamanya. Saat sekarang ini dikatakannya sebagai masa yang telah memasuki akhir jaman.

Demikian data-data yang peneliti peroleh tentang pemahaman keagamaan dari para pelajar sekolah tingkat menengah atas. Berdasarkan data tersebut, peneliti membuat analisa sebagai berikut:

Para pelajar memperlihatkan penguasaan informasi keagamaan dasar dalam agama Islam. Setidaknya hal itu terisyaratkan dalam pemahaman mereka terhadap beberapa tema, diantaranya tentang arti Islam, pokokpokok ajarannya, sejarah, dan isu-isu keagamaan terkini. Makna Islam bagi 
para pelajar ini hampir serupa. Diaz Maulida (NISN. 0027730412) memaknai Islam sebagai selamat. Hal ini tercermin pada ucapan salam yang diucapkan oleh umat Islam saat mereka saling bertemu dan menyapa. Makna yang demikian seirisan dengan makna damai yang diutarakan oleh Syavian Deniswara (NISN. 0026936740) dan Farrel Abhista El Rasya (NISN. 0027044427). Vian menambahkan bahwa dengan makan damai yang demikian, umat Islam dituntun oleh agamanya untuk menjalani kehidupan rukun dengan sesama. Farrel menyebut istilah rahmatan lil alamain (rahmat bagi seluruh alam) saat merujuk ke makna damai dalam Islam. Di sisi lain, Elza Khairunnisa Ramadani (NISN. 0018693327) dan Anugrah Ramadhan Rahandi (NISN. 0019092882) mempunyai kemiripan pemahaman tentang makna Islam. Elza menyebutkan tentang ketegasan dan kedisiplinan, sedang Anu mengutarakan tentang ketat dan banyaknya aturan dalam Islam.

Terkait dengan tema pokok-pokok ajaran Islam, hampir semua responden pelajar ini merujuk kepada rukun Islam dan rukun Iman. Mereka juga menguraikan satu persatu makna dari masing-masing rukun tersebut. Selain tentang rukun ini, tiga responden yaitu Anugrah Ramadhan Rahandi (NISN. 0019092882), Farrel Abhista El Rasya (NISN. 0027044427), dan Fito Agrianto (NISN. 0022790873) menyebutkan tentang al-qur'an sebagai kitab suci umat Islam yang merupakan landasan dasar dalam beragama.

Pemahaman para pelajar tentang tema sejarah agama Islam tampak minim dan belum tertata dengan baik. Hal ini terlihat saat sesi FGD (Focus Group Discussion) atau wawancara berlangsung. Mereka kurang tangkas dalam menjelaskan perihal sejarah. Saat para responden menguraikan tentang sejarah agama Islam, mereka hanya mengutarakannya secara global. Misalnya Syavian Deniswara (NISN. 0026936740) mengatakan bahwa nasib kum wanita sebelum Islam sangat memprihatinkan, kemudian datang agama Islam untuk memperbaikinya. Kemudian Fito Agrianto (NISN. 0022790873) menyatakan bahwa nabi Muhammad adalah pembawa agama Islam. Diaz Maulida (NISN. 0027730412) menyebutkan tentang Nabi Muhammad yang 
ditugaskan untuk menyebarkan agama Islam yang bertujuan untuk menyempurnakan agama-agama terdahulu. Sedang Anugrah Ramadhan Rahandi (NISN. 0019092882) dan Farrel Abhista El Rasya (NISN. 0027044427) menyebutkan hal yang sama terkait dengan sejarah, yaitu tentang perang salib. Anu menambahkan perihal hijrah nabi Muhammad dari Makkah ke Madinah.

Pengaruh media online sebagai ruang publik virtual tampak saat para pelajar menguraikan tema tentang isu-isu terkini yang terkait dengan keagamaan. Tidak hanya isu nasional yang mereka sampaikan, isu internasional pun mereka utarakan. Misalnya Diaz Maulida (NISN. 0027730412) dan Elza Khairunnisa Ramadani (NISN. 0018693327) bercerita tentang adanya kelompok ISIS (Islamic State of Iraq and Syria). Bahkan Diaz juga mengutarakan tentang sumber dana dan pembentuk awal kelompok radikal ini. Anugrah Ramadhan Rahandi (NISN. 0019092882) menegaskan juga tentang maraknya aksi terorisme tahun-tahun terakhir. Sedangkan Syavian Deniswara (NISN. 0026936740) dan Farrel Abhista El Rasya (NISN. 0027044427) menyoroti konflik dan perang yang tak berkesudahan antara Palestina dan Israel. Sedang isu keagamaan berskala nasional diungkapkan oleh Farrel, yaitu tentang kerusuhan Tolikara Papua.

Berdasarkan pemaparan di atas, maka terdapat kesan yang kuat pada diri para pelajar ini bahwa mereka menggambarkan agama sebagai sebuah kekuatan dan ketegasan. Memang, ketika memaknai kata Islam, beberapa pelajar merujuk ke kata selamat dan damai, sedang sebagian yang lain mengacu ke kata tegas dan disiplin. Tetapi ketika mengungkapkan perihal peristiwa-peristiwa, baik yang menyangkut tentang sejarah agama Islam maupun isu-isu keagamaan terkini, terdapat tema-tema yang selalu diungkapkan oleh beberapa responden yang berbeda. Perihal sejarah Islam, tema perang Salib menjadi pembicaraan yang cukup menonjol. Mereka menyebutkan tentang konflik agama antara Islam dan Kristen di masa lalu itu sebagai sesuatu yang penting dalam kajian sejarah Islam. Sedang perihal isu- 
isu keagamaan terkini, tema-tema seputar konflik kembali mengemuka dan menjadi topik pembicaraan, diantaranya tentang ISIS (Islamic State of Iraq and Syria), peperangan antara Palestina dan Israel, pengusiran dan pembunuhan Muslim Rohingya, serta tentang kerusuhan di Tolikara. Dengan demikian, ketika para pelajar tersebut menjabarkan perihal peristiwaperistiwa yang terkait dengan keagamaan, penggambaran agama sebagai sebuah kekuatan dan ketegasan muncul.

Dalam pandangan peneliti, penggambaran para pelajar tentang informasi keagamaan yang dipahaminya itu, yaitu sebagai sebuah kekuatan dan ketegasan, terkait erat dengan sumber data yang mereka peroleh. Sebagai generasi post-millenal yang selalu berkutat dengan ruang publik virtual, para pelajar mendapatkan informasi keagamaan terkini dari dunia internet, meskipun tentunya mereka mendapatkannya di bangku sekolah. Ruang publik virtual yang baik dan penuh dengan nilai-nilai positif akan mendorong para pengaksesnya ke arah yang positif pula. Tetapi sebaliknya, jika ruang publik virtual tersebut penuh dengan ujaran kebencian dan hal-hal yang mengindikasikan nilai-nilai negatif, maka para pengakses ruang publik virtual itu juga akan mengikuti pola yang negatif tersebut.

\section{KESIMPULAN}

Penelusuran terhadap pemahaman para pelajar terkini yang terkungkung dalam dunia virtual yang digitalistik terhadap ajaran dasar agama Islam menunjukkan adanya kesan ketegasan dan kekuatan, terutama saat menguraikan berbagai peristiwa yang bertalian dengan sejarah agama Islam maupun isu-isu keagamaan terkini. Ruang publik virtual yang melingkupi kehidupan para pelajar memberikan andil dalam penyebaran informasi keagamaan yang dapat terakses. Maka gambaran tentang pemahaman keagamaan adalah juga gambaran tentang ruang publik virtual yang sedang berlangsung saat ini. 


\section{DAFTAR PUSTAKA}

Azwar, S. (2010). Metode Penelitian. Pustaka Pelajar.

Bogdan, R., \& Biklen, S. K. (1982). Qualitative Research for Education: An Introduction to Theories and Methods. Allyn and Bacon.

Dwiana, R. (2013). Mobilisasi Massa dalam Era Network Society. Jurnal Pekommas, 16(3), 155-162. https://doi.org/10.30818/jpkm. $\underline{2013.1160302}$

Kilp, A. (2011). Religion in the Construction of the Cultural "Self" and "Other." Estonian National Defence College Proceedings, 14, 197-222.

Nasrullah, R. (2012). Internet dan Ruang Publik Virtual, Sebuah Refleksi atas Teori Ruang Publik Habermas. Jurnal Komunikator, 4(1), 26-35.

Piliang, Y. A. (2017, December 10). Digitalisasi dan Multiplikasi-Perbedaan Konsep 'Difference' dalam Cyberspace. Seminar Nasional Filsafat 'Implikasi Filosofis Kultur Digital,' Bandung.

Spears, R. (2011). Group Identities: The Social Identity Perspective. In S. J. Schwartz, K. Luyckx, \& L. V. Vivian (Eds.), Handbook of Identity Theory and Research: Vol. Structures and Processes (pp. 201-224). Springer.

Sugiyono. (2012). Metode Penelitian Kuantitatif Kualitatif dan R\&D. Alfabeta.

Tim Pusat Pengkajian Islam dan Masyarakat. (2017). Api Dalam Sekam: Keberagamaan Gen Z. UIN Syarif Hidayatullah.

Wulan Pujiriyani, D. (2013). Re-Imajinasi Ke-Indonesia-an dalam Konteks 'Network Society.' Jurnal Komunitas, 5(2), 151-161. https://doi.org/10.15294/komunitas.v5i2.2734 